\title{
Infection Prevention in the Emergency Department
}

\author{
Stephen Y. Liang, MD ${ }^{a, b}$, Daniel L. Theodoro, MDa, Jeremiah D. Schuur, MD, MHS ${ }^{c}$, and \\ Jonas Marschall, MD ${ }^{d}$
}

aDivision of Emergency Medicine, Washington University School of Medicine, St. Louis, Missouri, USA bivision of Infectious Diseases, Department of Medicine, Washington University School of Medicine, St. Louis, Missouri, USA 'Department of Emergency Medicine, Brigham and Women's Hospital, Boston, Massachusetts, USA dDepartment of Infectious Diseases, Bern University Hospital and University of Bern, Bern, Switzerland

\begin{abstract}
Infection prevention remains a major challenge in emergency care. Acutely ill and injured patients seeking evaluation and treatment in the emergency department (ED) not only have the potential to spread communicable infectious diseases to healthcare personnel and other patients, but are vulnerable to acquiring new infections associated with the care they receive. This article will evaluate these risks and review the existing literature for infection prevention practices in the ED, ranging from hand hygiene, standard and transmission-based precautions, healthcare personnel vaccination, and environmental controls to strategies for preventing healthcare-associated infections. We will conclude by examining what can be done to optimize infection prevention in the ED and identify gaps in knowledge where further research is needed. Successful implementation of evidence-based practices coupled with innovation of novel approaches and technologies tailored specifically to the complex and dynamic environment of the ED are the keys to raising the standard for infection prevention and patient safety in emergency care.
\end{abstract}

\section{Introduction}

Infection prevention is a major challenge in the rapid-paced, high-volume setting of emergency care. The emergency department (ED) is a complex and dynamic healthcare environment. Patients present with undifferentiated illnesses and variable acuity, ranging from the otherwise healthy to the critically ill. Risk recognition and medical decisionmaking are often based on limited and evolving data, under significant time and resource constraints. Patients await diagnosis, intervention, and disposition in close proximity of one

(C) 2014 American College of Emergency Physicians. Published by Mosby, Inc. All rights reserved

Corresponding author: Stephen Y. Liang, MD Divisions of Emergency Medicine \& Infectious Diseases Washington University School of Medicine 660 S. Euclid Avenue, Campus Box 8051 Saint Louis, Missouri 63110-1093 Phone: (314) 747-0750 Fax: (314) 454-5392 sliang@dom.wustl.edu.

Publisher's Disclaimer: This is a PDF file of an unedited manuscript that has been accepted for publication. As a service to our customers we are providing this early version of the manuscript. The manuscript will undergo copyediting, typesetting, and review of the resulting proof before it is published in its final citable form. Please note that during the production process errors may be discovered which could affect the content, and all legal disclaimers that apply to the journal pertain.

Conflicts of interest: None (SYL, DLT, JDS, JM) 
another. With more than 129.8 million patient visits made to U.S. EDs in 2010 alone, the ED is a busy place subject to rapid patient turnover and even overcrowding. ${ }^{1}$ The ED is a major gateway to inpatient medical care, contributing nearly half of all hospital admissions. ${ }^{2}$ It also constitutes our healthcare system's frontline in the response to public health emergencies and disasters. Amidst these diverse roles and competing demands, infection prevention can easily be overlooked or superseded by other immediate and life-threatening issues. Yet, significant infectious disease risks exist in emergency care that can carry substantial clinical consequences for both patients and healthcare personnel (HCP).

This article will address infection prevention in the ED through two central themes: 1) preventing the transmission of infectious diseases from ill patients to HCP and to other patients, and 2) reducing the risk of infection associated with receiving emergency care. We will review the existing literature behind ED hand hygiene, standard and transmission-based isolation precautions, HCP vaccination, and environmental controls. Next, we will examine the threat of healthcare-associated infections (HAI) related to central venous catheters, urinary catheters, mechanical ventilation, and other medical devices commonly used in the ED. We will conclude by identifying areas in which we can improve infection prevention in the ED today, as well as highlight gaps in knowledge that would benefit from further investigation as we look to the future.

\section{Preventing the transmission of infectious organisms in emergency settings}

\section{Hand Hygiene}

Ignaz Semmelweis first recognized the fundamental role of hand hygiene in curbing the spread of contagion more than a century and half ago while working in the obstetrics wards of Vienna General Hospital. At a time when puerperal fever was common and often fatal, Semmelweis demonstrated that physician hand disinfection with a chlorinated lime solution could lead to a significant decline in the incidence and mortality of this disease. To this day, hand hygiene remains the cornerstone of modern infection prevention and is the single most important strategy for curbing transmission of infectious microorganisms between patients, $\mathrm{HCP}$, and the healthcare environment. ${ }^{3}$

While normal human skin is routinely colonized with resident bacterial flora (e.g., coagulase-negative Staphylococcus), transient flora can contaminate the skin of HCP through direct patient contact or contact with the patient's immediate environment. ${ }^{3,4}$ Transient flora can include Staphylococcus aureus, Enterococcus, Gram-negative bacilli, and $C$. difficile, all of which have been associated with HAIs, as well as a host of respiratory and gastrointestinal viruses. When performed regularly and correctly, hand hygiene eliminates transient flora, thereby disrupting transmission of these microorganisms. ${ }^{3}$ Alcohol-based gel and foam products are superior to regular and antimicrobial soap in reducing bacterial counts, and are therefore recommended for most routine hand hygiene. They also incur less of a time burden than soap and water, which may improve adherence to their use. ${ }^{5,6}$ Hospital-wide hand hygiene programs employing alcohol-based hand rubs have been credited with dramatic reductions in HAIs. ${ }^{7,8}$ However, scrubbing and rinsing with soap and water is still preferred when caring for patients with $C$. difficile infection, as alcohol-based products are not effective against $C$. difficile spores, or when there is visible 
soiling of the hands. Hand hygiene should be performed anytime HCP enter the 3-foot space around a patient, as the immediate environment and equipment surrounding the patient can be readily contaminated. The Centers for Disease Control and Prevention (CDC) and the World Health Organization (WHO) provide valuable guidance on effective hand hygiene practices. ${ }^{3,9}$

Hand hygiene adherence has been shown to be lower in settings with high patient activity, such as the intensive care unit (ICU), and among physicians. ${ }^{10}$ Early studies of ED hand hygiene echo these trends. ${ }^{1-14}$ More recently, ED hand hygiene adherence rates have ranged anywhere from $10 \%$ to $90 \% .{ }^{15-19}$ Variable adherence with hand hygiene in the ED has been attributed to lack of time, urgent clinical situations, and high patient workload. Lower hand hygiene adherence has also been associated with caring for patients in ED hallways, a marker for high ED visit volume and a surrogate for overcrowding. ${ }^{18}$

Much of the existing literature on hand hygiene implementation is comprised of quasiexperimental studies. Interventions addressing ED hand hygiene practices have been met with differing success (Table 1). At the level of the individual provider, interventions have ranged from posting high visibility signs promoting hand hygiene and circulating educational materials to staff to trialing touch-free as well as personal wearable hand sanitizer dispensers. ${ }^{14,20,21}$ Workflow optimization and standardization have also been examined as a means of streamlining bedside procedures and reducing extraneous hand hygiene events in the course of patient care. ${ }^{22}$ Larger, multifaceted interventions incorporating group and one-on-one education, a shared culture of patient safety, designated clinician champions to promote and model proper hand hygiene, improved access to alcohol-based hand rub, and routine hand hygiene monitoring through direct observation have led to sustained improvements in ED hand hygiene adherence. ${ }^{23-25}$ Immediate feedback about hand hygiene performance as well as regular reporting and dissemination of HCP adherence rates foster accountability and provide concrete benchmarks by which improvement can be measured. These studies align with a general consensus based on existing evidence that bundled interventions incorporating education, reminders, feedback, administrative support, and access to alcohol-based hand rub are our most effective means for improving hand hygiene adherence. ${ }^{26,27}$

\section{Standard precautions}

ED HCP routinely come in contact with blood and other potentially infectious body fluids (e.g., cerebrospinal, pleural, peritoneal, pericardial, synovial, amniotic) during patient care. ${ }^{28,}{ }^{29} \mathrm{Up}$ to two-thirds of procedures performed in the ED result in some form of HCP exposure to blood or other body fluid. ${ }^{30}$ Most exposures involve the hands. Exposures to the face are more likely to occur during tube thoracostomy, lumbar puncture, or examination of a hemorrhaging patient.

First introduced by the CDC in the 1980s due to the growing epidemic of human immunodeficiency virus (HIV) infection, standard precautions mandate the use of barriers (e.g., gloves, protective gowns, masks, and eye wear) to protect HCP from bloodborne pathogens such as HIV, hepatitis $\mathrm{B}$, and hepatitis $\mathrm{C},{ }^{31-33}$ as well as to prevent transmission of other infectious microorganisms. They are indicated when contact with blood or other 
body fluids, mucous membranes, non-intact skin, or potentially infectious material is anticipated. Face and eye protection are recommended for procedures and examinations where splashes or sprays of blood or other body fluids are likely. Eye wear must consist of a face shield, goggles, or glasses with side shields in order to be considered protective. Standard precautions also encompass hand and respiratory hygiene as well as the safe handling of potentially contaminated equipment and environmental surfaces. ${ }^{34}$ Previously referred to as universal precautions, standard precautions are one of the most extensively studied infection prevention strategies in emergency care. Despite CDC guidelines and a mandate from the Occupational Safety and Health Administration (OSHA) since 1991, 35 the day-to-day practice of standard precautions and use of personal protective equipment (PPE) in the ED remains highly variable. Several studies performed in U.S. academic medical centers have employed either direct observation or video recording during trauma and medical resuscitations to measure adherence, ${ }^{36-42}$ and have reported rates ranging from $38 \%$ to $89 \%$. In some cases, $\mathrm{HCP}$ adherence to standard precautions improved if a patient was visibly bleeding. ${ }^{39,43}$ Yet, other studies have demonstrated the opposite, underscoring how clinical urgency can compete with infection prevention practices in acute situations. $37,40,44$ During resuscitations, ED HCP are more likely to wear gloves than a gown, mask, or protective eye wear. The same holds true during non-emergent clinical encounters, despite the potential for exposure to blood and other body fluids. ${ }^{12,43,45,46}$ In surveys of ED HCP, commonly cited barriers to adherence to standard precautions have included lack of time, a perception that a patient is at low risk for being infected with HIV or another bloodborne pathogen, interference with dexterity and technical skills, and poor access to PPE at the bedside. ${ }^{47-51}$ In some cases, HCP also report uncertainty of which protective barriers to use and when, reflecting inadequate training or knowledge retention. ${ }^{52,53}$

Several intervention studies have sought to improve HCP adherence to standard precautions in the ED (Table 2). ${ }^{44,54-58}$ Educational programs have employed in-service lectures, smallgroup discussions, and written materials highlighting the risks posed by bloodborne pathogens. ${ }^{54,56-58}$ One study also incorporated group review of a resuscitation video recording showing poor adherence to standard precautions. ${ }^{58}$ Visual cues at the patient bedside in the form of posters along with verbal reminders from supervising staff have helped to reinforce adherence. ${ }^{44,56,58}$ Bundling of supplies in designated supply carts or pre-organized packs provides immediate access to PPE and facilitates their use in resuscitation settings. ${ }^{44,57}$ Adherence monitoring through "environmental safety" rounds 55 or less formal means ${ }^{57}$ accompanied by the threat of disciplinary action with repeated lapses in adherence has likewise been shown to be effective. Although not studied as an intervention, pre-notification and assembly of the trauma team in the resuscitation area prior to the arrival of a patient has also been associated with improved adherence to standard precautions. ${ }^{38}$

Given that exposure to blood and other body fluids during resuscitations and procedures is unpredictable, efforts to improve and sustain high levels of adherence to standard precautions must be a priority in the ED. Ready access to PPE, education, frequent reminders, and routine adherence monitoring can help reinforce the use of protective barriers in these high-risk situations. It is important to iterate that glove use is not a substitute for hand hygiene, as microscopic tears and skin contamination during glove removal can still 
result in the transmission of pathogens to the hands of HCP. ${ }^{59-61}$ Therefore, appropriate PPE use coupled with regular hand hygiene are necessary for standard precautions to be effective in protecting ED HCP.

\section{Transmission-based precautions}

Communicable infectious diseases can be transmitted through airborne droplet nuclei, large particle droplets, or direct contact with patients and their immediate environment. Given that knowledge of whether a patient is infected or colonized with a pathogen is seldom known at the time of presentation, empiric transmission-based precautions are crucial to preventing the spread of infectious microorganisms in the ED. ${ }^{62}$

Airborne precautions-Airborne droplet nuclei measuring $\varsigma \mu \mathrm{m}$ can remain infective and suspended in the air for hours at a time, particularly in enclosed and poorly ventilated spaces. Airborne transmission of tuberculosis, ${ }^{63-65}$ measles, ${ }^{66,67}$ and severe acute respiratory distress syndrome (SARS) ${ }^{68-70}$ has been described in ED settings. Varicella (including disseminated zoster), highly pathogenic influenza, and smallpox may also be transmitted in this manner. Rapid identification and isolation of ED patients suspected of harboring an airborne disease hinges greatly upon heightened clinical suspicion, as in the case of tuberculosis. ${ }^{71}$ Screening tools and clinical decision-making instruments can help inform this process. ${ }^{72,73}$

Proper HCP protection against airborne droplet nuclei requires use of either an N95 or powered air purifying respirator. ${ }^{62}$ In a survey of emergency medicine residents, selfreported adherence with respirator use during encounters with patients at risk for tuberculosis was low due to poor availability of masks and lack of appropriate fit testing. ${ }^{74}$ Likewise, during the SARS epidemic, many HCP infections were associated with inadequate use of PPE including respirators. ${ }^{75,76}$

Engineering controls aimed at mitigating or eliminating workplace hazards factor prominently in preventing airborne transmission of pathogens in the ED. ${ }^{62}$ Singleoccupancy airborne infection isolation rooms equipped with special air handling and ventilation systems (capable of $\geq 12$ air changes per hour) to generate negative room pressure have been associated with significant reductions in tuberculosis conversion rates among urban ED HCP caring for high-risk populations. ${ }^{77}$ Yet, the availability of such isolation facilities varies among EDs. ${ }^{78}$ Increased respirator availability, education, and fit testing combined with the construction, certification, and regular maintenance of airborne infection isolation rooms are necessary measures to assure the adequacy of ED airborne precautions.

Droplet precautions-Unlike airborne droplet nuclei, large particle droplets measuring $>5 \mu \mathrm{m}$ neither travel nor remain suspended in air for long periods. Droplet transmission occurs with seasonal influenza ${ }^{79}$ and meningococcal disease, ${ }^{80}$ both of which have been associated with transmission to and infection of ED HCP. Pathogens including Haemophilus influenzae, group A Streptococcus, Bordetella pertussis, and a host of other respiratory viruses are also transmitted by droplets. 
Donning a surgical mask as part of standard precautions provides sufficient droplet protection for $\mathrm{HCP}$ and is recommended when working within 3 feet of the patient. ${ }^{62} \mathrm{~A}$ more conservative radius for masking within 6 to 10 feet or upon entering the patient's room has also been suggested. While a single occupancy patient room is preferred, spatial distancing ( $\_$feet) and separation of patient beds by curtains are also acceptable methods of droplet isolation. Patient cohorting during outbreaks and peak respiratory virus season has also been shown feasible in the ED in order to limit transmission and increase surge capacity. ${ }^{81}$

When surveyed about patients presenting with influenza-like illness, emergency physicians and nurses report less than optimal adherence with surgical mask or glove use. ${ }^{82}$ As with airborne precautions, limited training and availability of respiratory PPE may be partly to blame. Lack of reminders about droplet precautions may also contribute. To this end, the electronic health record (EHR) can be a useful tool for improving ED HCP adherence. Electronic notification of physicians and nurses about the need for droplet precautions when placing an order for influenza testing in the EHR can effect modest improvements in adherence. ${ }^{83}$ Some of the challenges with HCP adherence to airborne and droplet precautions may also tie into how respiratory PPE impacts the therapeutic interaction between HCP and patients. ${ }^{84}$ Respirators and surgical masks form a highly visible physical barrier between the two that may not only interfere with clear communication but promote social distancing and isolation, further compounded when physical isolation of the patient is necessary. How much this actually influences HCP adherence to airborne and droplet precautions has not been well-studied.

Respiratory hygiene has emerged as a comprehensive approach to curbing transmission of respiratory infections in ED settings through direct engagement and empowerment of patients. ${ }^{85}$ Signs describing appropriate cough etiquette, improved access to hand hygiene supplies, masking and separation of ED patients presenting with respiratory symptoms, and $\mathrm{HCP}$ adherence to droplet precautions comprise this multifaceted approach ${ }^{62}$ In one study, adherence with self-masking remained low among patients presenting to the ED with cough, although many agreed that masks and hand hygiene were effective methods for preventing transmission of respiratory infections. ${ }^{86}$ More studies are needed to identify successful strategies for implementing and sustaining respiratory hygiene practices among HCP and patients in the ED.

Contact precautions-EDs frequently care for patients infected or colonized with multidrug-resistant organisms (MDRO) including methicillin-resistant Staphylococcus aureus (MRSA), ${ }^{87-91}$ vancomycin-resistant Enterococcus (VRE), ${ }^{87,} 91$ and a growing number of multidrug-resistant Gram-negative bacteria (e.g., Acinetobacter baumannii, Pseudomonas aeruginosa, and various Enterobacteriaceae). ${ }^{92}$ Clostridium difficile ${ }^{93,}, 94$ and other enteric pathogens ${ }^{95}$ are likewise commonly encountered in patients with diarrheal illness. Transmission of these pathogens and others, including SARS and highly pathogenic influenza, can occur through direct contact with patients or their immediate surroundings. Contact precautions entail the use of protective gowns and gloves during patient care to prevent HCP acquisition and transmission of these pathogens to other patients. ${ }^{62}$ With the exception of patients presenting with diarrhea or bowel incontinence, the decision to initiate 
contact precautions in the ED can be difficult. Policies guiding their use vary widely among EDs. ${ }^{96}$ Many hospital EHRs now automatically flag established patients with a past history of MDRO infection or colonization, ${ }^{97,}, 98$ allowing ED HCP to identify these patients and initiate contact precautions early on in their care. Others have implemented selective screening for MDROs and empiric use of contact precautions for any patient coming from a nursing home or long-term care facility. ${ }^{99}$ The extent of HCP adherence to contact precautions once the need has been identified is not yet known.

\section{Healthcare personnel vaccination}

Immunization is an important strategy for protecting ED HCP against vaccine-preventable diseases including hepatitis B, measles, mumps, rubella, pertussis, varicella, and seasonal influenza. ${ }^{100}$ Historically, influenza vaccination rates have been low among ED HCP. ${ }^{101-103}$ While influenza vaccination does not replace the practice of hand hygiene or droplet precautions, it can be effective in preventing infection if the vaccine is well-matched to prevalent strains circulating in the community. Annual influenza vaccination is widely encouraged for all persons aged six months and older with no medical contraindications. ${ }^{104}$ More research is needed to identify how education, increased vaccine availability, and employment conditional upon immunity can improve vaccination rates among ED HCP.

\section{Environmental controls}

Opportunities abound for contamination of environmental surfaces and medical equipment in the ED. Patients colonized or infected with MDROs, including MRSA, can transfer microorganisms to their gowns, linens, guard rails, overbed tables, blood pressure cuffs, the floor, and many other sites in their immediate vicinity. ${ }^{105,} 106$ Environmental contamination with MDROs contributes significantly to the contamination of HCP hands during patient care. ${ }^{60,107}$ Future patients can also acquire MDROs when hospitalized in a room previously occupied by a MDRO-colonized patient where environmental contamination has occurred. ${ }^{108,} 109$

The CDC provides comprehensive guidelines on disinfection and sterilization in healthcare settings that readily apply to the ED. ${ }^{110}$ Non-critical equipment (e.g., blood pressure cuffs) and environmental surfaces (e.g., bed rails, patient furniture, floors), defined as those that primarily come into contact with intact patient skin, should receive low-level disinfection between patients. Limited evidence supports that, with adequate routine environmental cleaning, the risk of persistent contamination of high-touch patient care objects (e.g., chairs, gurneys, examination tables, curtains) in the ED is minimal. ${ }^{111,112}$ Studies addressing how effective environmental cleaning and disinfection practices can be implemented and reliably maintained in the ED while permitting rapid turnover of patient rooms would be greatly beneficial.

MRSA has also been isolated from communal objects in the ED that may escape regular disinfection including computer keyboards, phones, and door keypads. ${ }^{111-113}$ Provider stethoscopes are frequently contaminated. ${ }^{114-116}$ Whether these objects contribute to transmission of MDROs in the ED is not clear, but it would seem prudent to incorporate their routine disinfection into environmental cleaning and disinfection practices. 


\section{Healthcare-associated infections in emergency settings}

Up to this point, we have discussed ED infection prevention in the context of caring for patients presenting with communicable infectious diseases and disrupting pathogen transmission. It is equally important to turn our attention to how we can protect patients from acquiring new infections as a result of receiving emergency care. One in twenty Americans will develop a healthcare-associated infection (HAI) in the course of a hospitalization. Across the U.S., HAIs claim almost 100,000 lives annually. ${ }^{117}$ While the burden of HAIs directly attributable to ED care is unknown, the ED is a setting in which invasive procedures are frequently performed and place patients at risk for device-related infections. We will examine what interventions have been explored in the ED environment to prevent HAIs. (Table 3)

\section{Central line-associated blood stream infection}

Central venous catheters (CVC) are inserted for many emergent indications in the ED including volume resuscitation in trauma, early goal-directed therapy in sepsis, and when peripheral vascular access is not possible. Central line-associated blood stream infections (CLABSI) extend ICU and hospital length of stay, and account for anywhere between \$296 million to $\$ 2$ billion in annual spending. ${ }^{118-121}$ CLABSIs can also increase attributable mortality by up to $30 \% .^{122,123}$

Studies examining outcomes of ED CVCs have focused more on acute mechanical complications than CLABSI, most likely due to inadequate surveillance mechanisms for tracking outcomes. ${ }^{124-126}$ Prior to 2010, ED CLABSI studies suffered from imprecise definitions and lacked sufficient power. Reported CLABSI rates for ED CVCs varied from 0 to 24.1 CLABSIs per 1,000 catheter days depending on patient population and anatomical factors such as insertion site. ${ }^{127-130}$ Significant heterogeneity among these studies precludes pooling of their results. ${ }^{126}$ Since 2010, only one study has described the incidence of CLABSI attributed to the ED and found that, in an academic medical center, ED CLABSI rates were similar to that of the ICU. ${ }^{131}$ Relying primarily on administrative databases of ED patients admitted to the ICU, the rate of ED CLABSI was 1.93 per 1,000 catheter-days (95\% CI 0.50-3.36). The generalizability of this finding remains untested.

Historically, ED CLABSI studies have focused on aseptic technique during CVC insertion. Video-based assessments have reported HCP adherence ranging from $33 \%$ to $88 \%$, with lower rates among senior physicians. ${ }^{132,133}$ Simulation-based training improves adherence to aseptic technique and has been associated with a reduction in CLABSI rates. ${ }^{134}$ Successful strategies to prevent CLABSI in the ICU revolve around comprehensive bundles incorporating education, hand hygiene, use of maximal sterile barrier precautions (surgical gown, sterile gloves, mask, cap, and large sheet drape), chlorhexidine-alcohol skin antisepsis, and avoidance of the femoral vein due to the high infection rate associated with CVC insertion at this site. ${ }^{135,136}$ Standardized CVC kits and equipment carts provide easy access to supplies needed to conform to these practices. Universal CVC insertion checklists provide cues for each of the components and facilitate documentation of adherence to CLABSI prevention measures during the procedure. An observer is designated to review the checklist, monitor aseptic technique, and terminate the procedure should a protocol violation 
occur. Such systems-based prevention strategies have significantly reduced CLABSI rates in ICUs. ${ }^{137,138}$ Among EDs that have adopted this approach to CVC insertion, successful bundle implementation has been tied to recruitment of clinician champions, staff engagement, clear staff responsibilities, workflow redesign, observer empowerment, and feedback through adherence and CLABSI surveillance data. ${ }^{139}$ As of yet, there are no published data on the effects of the checklist and bundle approach on ED CLABSI rates. Formal surveillance of CVCs placed in the ED remains a challenge. The impact of early discontinuation of ED CVCs once they are no longer needed on ED CLABSI rates has not been evaluated. ${ }^{126}$

Peripheral venous catheters (PVC) are a mainstay of medical therapy in the ED. While PVC infections are uncommon, bloodstream infection ${ }^{140,141}$ and even septic thrombophlebitis may occur in rare instances. At one academic institution, the estimated incidence of PVCrelated S. aureus bacteremia was 0.07 per 1,000 PVC-days, with more than half of all infected PVCs originating in the ED. ${ }^{141}$ Overall adherence to aseptic technique during PVC insertion and line care during infusions have been shown to be poor in the ED. ${ }^{142}$

Educational programs paired with direct observation during insertions and feedback on performance can improve adherence and reduce infections associated with PVCs. ${ }^{142}$ Avoidance of unnecessary ED PVCs may also reduce infection rates although this has not been formally studied. For patients with difficult vascular access, ultrasound-guided PVCs have emerged as an alternative to CVCs in non-critically ill patients. ${ }^{143}$ With proper aseptic technique, infection rates associated with ultrasound-guided PVCs do not differ significantly from that of traditional PVCs. ${ }^{144}$

\section{Catheter-associated urinary tract infection}

Urinary catheters are commonly used in the ED to manage acute urinary retention, bladder outlet obstruction, or hematuria associated with clots as well as to monitor urine output in critically ill patients. Left in place for prolonged periods of time, they can become colonized with bacteria leading to catheter-associated urinary tract infection (CAUTI) and sepsis. It is estimated that anywhere from $65-70 \%$ of CAUTIs are preventable. ${ }^{145}$ Several guidelines summarize evidence-based strategies for preventing CAUTI in acute care settings. ${ }^{146,147}$

While urinary catheters play an important role in medical care, inappropriate use of urinary catheters is common in ED and inpatient settings, ${ }^{148,} 149$ particularly among elderly patients. ${ }^{150,151}$ Although lack of medical documentation for a urinary catheter has been construed as inappropriate use in many studies, non-indications for catheter use among elderly patients in the ED have also included urine specimen collection, dementia, incontinence, patient request, immobility, and the need for output monitoring outside of the ICU. ${ }^{151}$ At one hospital, $73 \%$ of patients undergoing urinary catheter insertion in the ED were age 65 years or greater. ${ }^{152}$ In this group of 277 elderly catheterized patients, 24 developed CAUTI $(8.7 \%)$, of which 11 (4\%) were attributed to an inappropriate urinary catheter.

Several quasi-experimental studies have fielded strategies to reduce inappropriate use of urinary catheters in the ED. The introduction of an educational program targeting ED physicians and nurses and mandatory completion of a checklist of acceptable indications for 
urinary catheters prior to insertion resulted in an almost $80 \%$ reduction in ED catheter insertions. ${ }^{153}$ At the same time, appropriate use of catheters increased from $37 \%$ to $51 \%$ $(\mathrm{P}=0.06)$ and physician order documentation from $43 \%$ to $63 \%(\mathrm{P}<0.01)$. Another study also reported significant reductions in catheter utilization after guidelines were established for catheter insertion and reinforced by an educational program consisting of lectures and distribution of pocket cards listing appropriate indications. ${ }^{154}$ Efforts to reduce catheter utilization among resident physicians using an educational intervention have been less successful. ${ }^{155}$ Other efforts have sought to improve procedural knowledge and technique among ED nurses and other staff directly involved in catheter insertion. ${ }^{156}$ Outside the ED, multidisciplinary strategies promoting guidelines for appropriate indications for ED catheter placement, a nurse-driven protocol for early catheter removal, and routine monitoring of inpatient urinary catheter prevalence rates have led to sustained hospital-wide reductions in catheter use $\mathrm{e}^{157}$ that have been replicated on a population scale. ${ }^{158}$

\section{Ventilator-associated pneumonia}

Emergent endotracheal intubation is often necessary in ED patients presenting with respiratory failure, either from impaired ventilation or oxygenation, or to protect a patient's airway in the setting of trauma or other critical illness. Defined as pneumonia acquired in the hospital after more than 48 hours of mechanical ventilation that was not present at the time of intubation, ventilator-associated pneumonia (VAP) carries significant morbidity and variable mortality. ${ }^{159,160}$ Several studies have shown that trauma patients requiring intubation in the ED or prehospital setting may be predisposed to VAP for a variety of reasons, ranging from injury severity, hemodynamic instability, and depressed mental status to suboptimal intubation conditions resulting in aspiration. ${ }^{161-165}$ Increased ED length of stay has also been identified as an independent risk factor for pneumonia in emergently intubated trauma patients. ${ }^{166}$

With at least half of all cases of VAP considered preventable, ${ }^{145}$ several guidelines exist outlining simple and low-cost strategies to minimize aspiration of secretions, reduce colonization of the patient's respiratory tract with pathogenic bacteria, and prevent contamination of mechanical ventilation equipment. ${ }^{167,168}$ Studies have demonstrated that multifaceted interventions based on these guidelines may be associated with reductions in VAP rates, ${ }^{169,} 170$ although controversy still exists. Nursing interventions including routine suctioning above the endotracheal cuff, elevating the head of the bed at least 30 degrees, and providing oral hygiene with $1.5 \%$ hydrogen peroxide solution can be readily implemented in the ED with appropriate education, testing, and adherence monitoring. ${ }^{171}$ Limiting the duration of mechanical ventilation in carefully selected ED patients through early extubation has been shown to be safe, ${ }^{172}$ although the impact of this on VAP rates has not yet been studied.

\section{Other medical devices}

The growing use of bedside ultrasound in emergency care has greatly enhanced our ability to rapidly identify life-threatening conditions and safely perform invasive procedures such as CVC insertion. Ultrasound is also used to evaluate skin and soft infections (SSTI) for abscesses amenable to incision and drainage. At one academic institution, clinically 
significant pathogens including MRSA were identified in $70 \%$ of cultures obtained from ED ultrasonographic probes immediately after use in a convenience sample of patients presenting with SSTI. ${ }^{173}$ With appropriate disinfection practices using antimicrobial wipes, contamination of ultrasonographic probes with MRSA remains uncommon. ${ }^{173-175}$ Transvaginal ultrasonography has been used in the ED to evaluate complaints of vaginal bleeding and pelvic pain, as well as to diagnose early intrauterine pregnancy. In one study, human papillomavirus (HPV) contamination of transvaginal, or endocavitary, probes using polymerase chain reaction (PCR) was identified in $7.5 \%$ of surveillance samples. ${ }^{176}$ More concerning, HPV was identified on $21 \%$ of probes used to evaluate known HPV carriers, despite use of a probe cover and low-level disinfection. Endocavitary probes are considered semi-critical items because they contact mucous membranes and therefore require high-level disinfection between patient use. ${ }^{110}$ Appropriate ED decontamination guidelines and practices are necessary to prevent bedside ultrasound machines from becoming a vector for pathogens.

\section{Future Directions}

Ample opportunities exist to improve infection prevention in the ED, both through the implementation and optimization of best practices and future research. (Table 4) Current efforts should be prioritized towards areas that have shown the most sustainable changes. While essential to increasing HCP knowledge about established infection prevention practices, education alone does not maintain high levels of adherence. Policies and guidelines will not have an impact unless they are observed. ${ }^{177}$ Obstacles to ED infection prevention need to be understood, addressed, and overcome. Readily accessible PPE, alcohol-based hand rub dispensers, and other critical infection prevention supplies increase the likelihood that $\mathrm{HCP}$ will routinely use them in the course of patient care. Frequent reminders and feedback reinforce education and prompt HCP to perform key infection prevention practices at the bedside where competing clinical demands are high. Open communication among HCP about breaches in these practices foster accountability, trust, and a team mentality. Checklists and bundles ease our dependence on memory alone to complete complex tasks and promote high reliability care. Formal adherence monitoring and HAI surveillance provide concrete metrics by which performance improvement can be measured and relayed back to HCP. Finally, commitment and support from ED clinical and administrative leaders seal the foundation for a shared culture of safety. In this environment, ED infection prevention becomes both an organizational as well as an individual responsibility. While fewer studies have targeted infection prevention practices in the ED than in other healthcare settings, there is evidence that this comprehensive, multifaceted approach can be successful.

The feasibility of many infection prevention strategies will vary from ED to ED depending on the resources and support that each can leverage. Hospital infection prevention committees can provide invaluable expertise and assistance in deciding which strategies to implement and how the ED can best contribute to hospital-wide initiatives. ED representation on these committees is strongly encouraged. As many hospitals transition to electronic documentation and computerized provider order entry, the EHR can serve as a powerful tool for implementing infection prevention strategies. Adherence to transmission- 
based precautions can be enhanced through automated HCP notifications and alerts. ${ }^{83}$ Bundled interventions to prevent CLABSI, CAUTI, and VAP can be directed through standardized electronic order sets. Innovations in automated technology to track the performance of hand hygiene and other infection prevention practices could soon replace the need for time-consuming direct observations, making it easier to measure adherence throughout the ED. Involvement of ED HCP and infection prevention specialists in the planning and design of future EDs can also greatly enhance the feasibility of many basic practices and ensure that sufficient engineering controls are incorporated (e.g., single patient rooms, airborne infection isolation rooms). ${ }^{178}$ Optimization of the built environment may not only minimize environmental contamination but facilitate cleaning and disinfection of hospital surfaces in the ED.

Looking to the future, many questions in infection prevention in the ED remain to be answered. Advances in molecular diagnostics are revolutionizing the way we screen for and diagnose infectious diseases. The ability to rapidly identify ED patients infected with tuberculosis, seasonal influenza, or a MDRO, such as MRSA, ${ }^{179}$ could lead to earlier institution of transmission-based precautions and reduced potential for transmission in the hospital. Such technology could also be applied to targeted surveillance of high-risk populations for colonization with MDROs (e.g., patients awaiting admission to the ICU or transferred from another healthcare facility or a nursing home). In hospitals with a high prevalence of MDROs, the ED could play a role in active surveillance, although the costs, benefits, and implications of ED-based surveillance have yet to be studied. Admitted patients needing contact isolation often wait longer in the ED until a suitable hospital room is available, ${ }^{180}$ which can contribute to overcrowding and even enhanced MDRO transmission if infection prevention practices are not well-adhered to. Strategies such as cohorting patients with MDROs or expediting their admission to an inpatient bed need to be explored. What constitutes expedient yet effective terminal cleaning of the ED environment after the care of patients infected or colonized with MDROs or $C$. difficile has to be defined and must be realistic to sustain patient throughput.

While the role of the ED in preventing HAIs will likely continue to expand, more accurate surveillance systems are necessary to determine the true percentage of CLABSIs, CAUTIs, and VAPs that are directly attributable to ED care. Novel methods to maintain aseptic technique during invasive ED procedures are needed, particularly in resuscitations. The impact of new technologies, such as antibiotic impregnated catheters, require validation in chaotic and time-sensitive settings such as the ED. Aggressive strategies to prevent HAIs, including universal decolonization, may be worth examining in at-risk ED patients, particularly in areas where the prevalence of MRSA is high. ${ }^{181}$

Antimicrobial stewardship encompasses the appropriate selection, dosing, route of administration, and duration of antimicrobial therapy to improve patient outcomes, reduce antimicrobial resistance, and prevent transmission of MDROs. The ED plays an important part in the responsible use of antimicrobial agents and preventing $C$. difficile infection through such stewardship. ${ }^{182}$ The development of new ED-based decision support tools could optimize antibiotic prescribing and eliminate unnecessary antibiotic use, particularly in patients that do not need to be admitted to the hospital.

Ann Emerg Med. Author manuscript; available in PMC 2015 September 01. 
In conclusion, the innovation and implementation of safe, practical, and effective infection prevention strategies tailored specifically to the ED is fertile grounds for future research and will have a lasting impact on patient safety in emergency care.

\section{Acknowledgement of grant or other financial support}

SYL received support from Grant Number KM1CA156708 through the National Cancer Institute (NCI) at the National Institutes of Health (NIH), Grant Number UL1RR024992 through the Clinical and Translational Science Award (CTSA) program of the National Center for Advancing Translational Sciences (NCATS), and the BarnesJewish Patient Safety \& Quality Career Development Program, which is funded by the Foundation for BarnesJewish Hospital. DLT received support from Grant Number K08 HS18092 at the Agency for Healthcare Research and Quality (AHRQ). JDS received support from Grant Numbers R13HS021616 and R18HS020013 from the AHRQ. JM received support from Grant Numbers KL2RR024994 and UL1RR024992 through the CTSA/NCATS, Grant Number 5K12HD001459-13 through the NIH Office of Research for Women's Health (ORWH), Grant Number U54 CK000162 (PI Fraser) as part of the Centers for Disease Control and Prevention (CDC) Epicenters Program, and the Barnes-Jewish Patient Safety \& Quality Career Development Program. The content is solely the responsibility of the authors and does not necessarily represent the official views of the NIH, NCATS, AHRQ, CDC, or the Foundation for Barnes-Jewish Hospital.

\section{References}

1. Centers for Disease Control and Prevention. National Center for Health Statistics. National Hospital Ambulatory Medical Care Survey. Emergency Department Summary Tables. 2010. [2/15/2014]; Available from: http://www.cdc.gov/nchs/data/ahcd/nhamcs_emergency/2010_ed_web_tables.pdf

2. Niska, R.; Bhuiya, F.; Xu, J. National Ambulatory Medical Care Survey: 2007 Emergency Department Summary. National Center for Health Statistics; Hyattsville, MD: 2010.

3. Boyce JM, Pittet D. Guideline for hand hygiene in health-care settings: recommendations of the Healthcare Infection Control Practices Advisory Committee and the HICPAC/SHEA/APIC/IDSA Hand Hygiene Task Force. MMWR Recomm Rep. 2002; 51(RR-16):1-45. [PubMed: 12418624]

4. Pittet D, Allegranzi B, Sax H, et al. Evidence-based model for hand transmission during patient care and the role of improved practices. Lancet Infect Dis. 2006; 6(10):641-52. [PubMed: 17008173]

5. Voss A, Widmer AF. No time for handwashing? Handwashing versus alcoholic rub: can we afford 100\% compliance? Infect Control Hosp Epidemiol. 1997; 18(3):205-8. [PubMed: 9090551]

6. Reardon JM, Valenzuela JE, Parmar S, et al. The time burden of alcohol-based hand cleanser when using nonsterile gloves. Infect Control Hosp Epidemiol. 2013; 34(1):96-8. [PubMed: 23221200]

7. Pittet D, Hugonnet $S$, Harbarth S, et al. Effectiveness of a hospital-wide programme to improve compliance with hand hygiene. Lancet. 2000; 356(9238):1307-12. [PubMed: 11073019]

8. Gordin FM, Schultz ME, Huber RA, Gill JA. Reduction in nosocomial transmission of drugresistant bacteria after introduction of an alcohol-based handrub. Infect Control Hosp Epidemiol. 2005; 26(7):650-3. [PubMed: 16092747]

9. WHO Guidelines on Hand Hygiene in Health Care: First Global Patient Safety Challenge Clean Care Is Safer Care. World Health Organization; Geneva: 2009.

10. Erasmus V, Daha TJ, Brug H, et al. Systematic review of studies on compliance with hand hygiene guidelines in hospital care. Infect Control Hosp Epidemiol. 2010; 31(3):283-94. [PubMed: 20088678]

11. Rumgay S, Macdonald S, Robertson CE. Hand-washing patterns and infection control in the accident and emergency department. Arch Emerg Med. 1984; 1(3):157-9. [PubMed: 6536279]

12. Roane CM. Registered nurses' use of universal barrier precautions in the pediatric emergency room. Pediatr Nurs. 1993; 19(5):453-5. [PubMed: 8233666]

13. Meengs MR, Giles BK, Chisholm CD, et al. Hand washing frequency in an emergency department. Ann Emerg Med. 1994; 23(6):1307-12. [PubMed: 8198306]

14. Dorsey ST, Cydulka RK, Emerman CL. Is handwashing teachable? Failure to improve handwashing behavior in an urban emergency department. Acad Emerg Med. 1996; 3(4):360-5. [PubMed: 8881546] 
15. Pittet D, Simon A, Hugonnet S, et al. Hand hygiene among physicians: performance, beliefs, and perceptions. Ann Intern Med. 2004; 141(1):1-8. [PubMed: 15238364]

16. Al-Damouk M, Pudney E, Bleetman A. Hand hygiene and aseptic technique in the emergency department. J Hosp Infect. 2004; 56(2):137-41. [PubMed: 15019226]

17. Saint S, Bartoloni A, Virgili G, et al. Marked variability in adherence to hand hygiene: a 5-unit observational study in Tuscany. Am J Infect Control. 2009; 37(4):306-10. [PubMed: 19135761]

18. Venkatesh AK, Pallin DJ, Kayden S, Schuur JD. Predictors of hand hygiene in the emergency department. Infect Control Hosp Epidemiol. 2011; 32(11):1120-3. [PubMed: 22011541]

19. Sánchez-Payá J, Hernández-García I, Camargo Ángeles R, et al. Hand hygiene in the emergency department: degree of compliance, predictors and change over time. Emergencias. 2012; 24:10712 .

20. Larson EL, Albrecht S, O'Keefe M. Hand hygiene behavior in a pediatric emergency department and a pediatric intensive care unit: comparison of use of 2 dispenser systems. Am J Crit Care. 2005; 14(4):304-11. [PubMed: 15980421]

21. Haas JP, Larson EL. Impact of wearable alcohol gel dispensers on hand hygiene in an emergency department. Acad Emerg Med. 2008; 15(4):393-6. [PubMed: 18370997]

22. Scheithauer S, Kamerseder V, Petersen P, et al. Improving hand hygiene compliance in the emergency department: getting to the point. BMC Infect Dis. 2013; 13:367. [PubMed: 23919402]

23. Saint S, Conti A, Bartoloni A, et al. Improving healthcare worker hand hygiene adherence before patient contact: a before-and-after five-unit multimodal intervention in Tuscany. Qual Saf Health Care. 2009; 18(6):429-33. [PubMed: 19955452]

24. di Martino P, Ban KM, Bartoloni A, et al. Assessing the sustainability of hand hygiene adherence prior to patient contact in the emergency department: A 1-year postintervention evaluation. Am J Infect Control. 2011; 39(1):14-8. [PubMed: 20965610]

25. Schuur, JD.; Kayden, S.; Goralnik, E. Ongoing monitoring, prompt feedback, and reminders improve hand hygiene in a busy, urban emergency department. Agency for Healthcare Research and Quality Healthcare Innovations Exchange. 2011. [2/15/2014]; Available from: http:// www.innovations.ahrq.gov/content.aspx?id=3071

26. Gould DJ, Moralejo D, Drey N, Chudleigh JH. Interventions to improve hand hygiene compliance in patient care. Cochrane Database Syst Rev. 2010; (9):CD005186. [PubMed: 20824842]

27. Schweizer ML, Reisinger HS, Ohl M, et al. Searching for an optimal hand hygiene bundle: a metaanalysis. Clin Infect Dis. 2014; 58(2):248-59. [PubMed: 24107409]

28. Jagger J, Powers RD, Day JS, et al. Epidemiology and prevention of blood and body fluid exposures among emergency department staff. J Emerg Med. 1994; 12(6):753-65. [PubMed: 7884193]

29. Denis MA, Ecochard R, Bernadet A, et al. Risk of occupational blood exposure in a cohort of 24,000 hospital healthcare workers: position and environment analysis over three years. J Occup Environ Med. 2003; 45(3):283-8. [PubMed: 12661185]

30. Kelen GD, Hansen KN, Green GB, et al. Determinants of emergency department procedure- and condition-specific universal (barrier) precaution requirements for optimal provider protection. Ann Emerg Med. 1995; 25(6):743-50. [PubMed: 7755194]

31. Centers for Disease Control and Prevention. Recommendations for preventing transmission of infection with human T-lymphotropic virus type III/lymphadenopathy-associated virus in the workplace. MMWR Morb Mortal Wkly Rep. 1985; 34(45):681-6. 691-5. [PubMed: 2997587]

32. Centers for Disease Control and Prevention. Recommendations for prevention of HIV transmission in health-care settings. MMWR Morb Mortal Wkly Rep. 1987; 36(Suppl 2):1S-18S.

33. Centers for Disease Control and Prevention. Guidelines for prevention of transmission of human immunodeficiency virus and hepatitis B virus to health-care and public-safety workers. MMWR Morb Mortal Wkly Rep. 1989; 38(Suppl 6):1-37.

34. Garner JS. The Hospital Infection Control Practices Advisory Committee. Guideline for isolation precautions in hospitals. Infect Control Hosp Epidemiol. 1996; 17(1):53-80. [PubMed: 8789689]

35. Occupational exposure to bloodborne pathogens-OSHA. Final rule. Fed Regist. 1991; 56(235): 64004-182. [PubMed: 10115865] 
36. Baraff LJ, Talan DA. Compliance with universal precautions in a university hospital emergency department. Ann Emerg Med. 1989; 18(6):654-7. [PubMed: 2729690]

37. Kelen GD, DiGiovanna TA, Celentano DD, et al. Adherence to universal barrier precautions during interventions on critically ill and injured emergency department patients. J Acquir Immune Defic Syndr. 1990; 3(10):987-94. [PubMed: 2398462]

38. DiGiacomo JC, Hoff WS, Rotondo MF, et al. Barrier precautions in trauma resuscitation: real-time analysis utilizing videotape review. Am J Emerg Med. 1997; 15(1):34-9. [PubMed: 9002566]

39. Evanoff B, Kim L, Mutha S, et al. Compliance with universal precautions among emergency department personnel caring for trauma patients. Ann Emerg Med. 1999; 33(2):160-5. [PubMed: 9922411]

40. Madan AK, Rentz DE, Wahle MJ, Flint LM. Noncompliance of health care workers with universal precautions during trauma resuscitations. South Med J. 2001; 94(3):277-80. [PubMed: 11284513]

41. Chiang WC, Wang HC, Chen SY, et al. Lack of compliance with basic infection control measures during cardiopulmonary resuscitation: are we ready for another epidemic? Resuscitation. 2008; 77(3):356-62. [PubMed: 18343557]

42. Kelleher DC, Carter EA, Waterhouse LJ, Burd RS. Compliance with barrier precautions during paediatric trauma resuscitations. Resuscitation. 2013; 84(3):314-8. [PubMed: 22841609]

43. Henry K, Campbell S, Collier P, Williams CO. Compliance with universal precautions and needle handling and disposal practices among emergency department staff at two community hospitals. Am J Infect Control. 1994; 22(3):129-37. [PubMed: 7943923]

44. Hammond JS, Eckes JM, Gomez GA, Cunningham DN. HIV, trauma, and infection control: universal precautions are universally ignored. J Trauma. 1990; 30(5):555-8. [PubMed: 2342138]

45. Henry K, Campbell S, Maki M. A comparison of observed and self-reported compliance with universal precautions among emergency department personnel at a Minnesota public teaching hospital: implications for assessing infection control programs. Ann Emerg Med. 1992; 21(8):9406. [PubMed: 1497161]

46. Rydman RJ, Tannebaum RD, Zalenski RJ. An evaluation of hospital emergency department (HED) adherence to universal precautions. J Med Syst. 1994; 18(4):207-20. [PubMed: 7829982]

47. Williams CO, Campbell S, Henry K, Collier P. Variables influencing worker compliance with universal precautions in the emergency department. Am J Infect Control. 1994; 22(3):138-48. [PubMed: 7943924]

48. Picheansathian W. Compliance with universal precautions by emergency room nurses at Maharaj Nakorn Chiang Mai Hospital. J Med Assoc Thai. 1995; 78(Suppl 2):S118-22. [PubMed: 7561585]

49. Kim LE, Evanoff BA, Parks RL, et al. Compliance with universal precautions among emergency department personnel: implications for prevention programs. Am J Infect Control. 1999; 27(5): 453-5. [PubMed: 10511495]

50. Madan AK, Raafat A, Hunt JP, et al. Barrier precautions in trauma: is knowledge enough? J Trauma. 2002; 52(3):540-3. [PubMed: 11901332]

51. Sundaram RO, Parkinson RW. Universal precaution compliance by orthopaedic trauma team members in a major trauma resuscitation scenario. Ann R Coll Surg Engl. 2007; 89(3):262-7. [PubMed: 17394711]

52. Ellison AM, Kotelchuck M, Bauchner H. Standard precautions in the pediatric emergency department: knowledge, attitudes, and behaviors of pediatric and emergency medicine residents. Pediatr Emerg Care. 2007; 23(12):877-80. [PubMed: 18091595]

53. Reid SM, Farion KJ, Suh KN, et al. Use of personal protective equipment in Canadian pediatric emergency departments. CJEM. 2011; 13(2):71-8. [PubMed: 21435312]

54. Talan DA, Baraff LJ. Effect of education on the use of universal precautions in a university hospital emergency department. Ann Emerg Med. 1990; 19(11):1322-6. [PubMed: 2240732]

55. Kelen GD, Green GB, Hexter DA, et al. Substantial improvement in compliance with universal precautions in an emergency department following institution of policy. Arch Intern Med. 1991; 151(10):2051-6. [PubMed: 1929694]

56. Friedland LR, Joffe M, Wiley JF, et al. Effect of educational program on compliance with glove use in a pediatric emergency department. Am J Dis Child. 1992; 146(11):1355-8. [PubMed: 1415077] 
57. Sahdev P, Lacqua MJ, Harrigan N, et al. Barrier precautions in trauma resuscitations: multivaried analysis of factors affecting use. Ann Emerg Med. 1994; 23(4):823-7. [PubMed: 8161054]

58. Brooks AJ, Phipson M, Potgieter A, et al. Education of the trauma team: video evaluation of the compliance with universal barrier precautions in resuscitation. Eur J Surg. 1999; 165(12):1125-8. [PubMed: 10636543]

59. Snyder GM, Thom KA, Furuno JP, et al. Detection of methicillin-resistant Staphylococcus aureus and vancomycin-resistant enterococci on the gowns and gloves of healthcare workers. Infect Control Hosp Epidemiol. 2008; 29(7):583-9. [PubMed: 18549314]

60. Hayden MK, Blom DW, Lyle EA, et al. Risk of hand or glove contamination after contact with patients colonized with vancomycin-resistant enterococcus or the colonized patients' environment. Infect Control Hosp Epidemiol. 2008; 29(2):149-54. [PubMed: 18179370]

61. Morgan DJ, Liang SY, Smith CL, et al. Frequent multidrug-resistant Acinetobacter baumannii contamination of gloves, gowns, and hands of healthcare workers. Infect Control Hosp Epidemiol. 2010; 31(7):716-21. [PubMed: 20486855]

62. Siegel JD, Rhinehart E, Jackson M, Chiarello L. Health Care Infection Control Practices Advisory Commitee. 2007 Guideline for isolation precautions: preventing transmission of infectious agents in health care settings. Am J Infect Control. 2007; 35(10 Suppl 2):S65-164. [PubMed: 18068815]

63. Haley CE, McDonald RC, Rossi L, et al. Tuberculosis epidemic among hospital personnel. Infect Control Hosp Epidemiol. 1989; 10(5):204-10. [PubMed: 2738388]

64. Sokolove PE, Mackey D, Wiles J, Lewis RJ. Exposure of emergency department personnel to tuberculosis: PPD testing during an epidemic in the community. Ann Emerg Med. 1994; 24(3): 418-21. [PubMed: 8080139]

65. Escombe AR, Huaroto L, Ticona E, et al. Tuberculosis transmission risk and infection control in a hospital emergency department in Lima, Peru. Int J Tuberc Lung Dis. 2010; 14(9):1120-6. [PubMed: 20819256]

66. Farizo KM, Stehr-Green PA, Simpson DM, Markowitz LE. Pediatric emergency room visits: a risk factor for acquiring measles. Pediatrics. 1991; 87(1):74-9. [PubMed: 1984623]

67. Bowen AC, Ferson MJ, Palasanthiran P. Consequences of an unrecognized measles exposure in an emergency department. Emerg Med Australas. 2009; 21(6):491-6. [PubMed: 20002720]

68. Varia M, Wilson S, Sarwal S, et al. Investigation of a nosocomial outbreak of severe acute respiratory syndrome (SARS) in Toronto, Canada. CMAJ. 2003; 169(4):285-92. [PubMed: 12925421]

69. Chen YC, Huang LM, Chan CC, et al. SARS in hospital emergency room. Emerg Infect Dis. 2004; 10(5):782-8. [PubMed: 15200809]

70. Chang WT, Kao CL, Chung MY, et al. SARS exposure and emergency department workers. Emerg Infect Dis. 2004; 10(6):1117-9. [PubMed: 15207066]

71. Moran GJ, McCabe F, Morgan MT, Talan DA. Delayed recognition and infection control for tuberculosis patients in the emergency department. Ann Emerg Med. 1995; 26(3):290-5. [PubMed: 7661416]

72. Solari L, Acuna-Villaorduna C, Soto A, et al. A clinical prediction rule for pulmonary tuberculosis in emergency departments. Int J Tuberc Lung Dis. 2008; 12(6):619-24. [PubMed: 18492327]

73. Moran GJ, Barrett TW, Mower WR, et al. Decision instrument for the isolation of pneumonia patients with suspected pulmonary tuberculosis admitted through US emergency departments. Ann Emerg Med. 2009; 53(5):625-32. [PubMed: 18760503]

74. Asimos AW, Kaufman JS, Lee CH, et al. Tuberculosis exposure risk in emergency medicine residents. Acad Emerg Med. 1999; 6(10):1044-9. [PubMed: 10530664]

75. Lau JT, Fung KS, Wong TW, et al. SARS transmission among hospital workers in Hong Kong. Emerg Infect Dis. 2004; 10(2):280-6. [PubMed: 15030698]

76. Seto WH, Tsang D, Yung RW, et al. Effectiveness of precautions against droplets and contact in prevention of nosocomial transmission of severe acute respiratory syndrome (SARS). Lancet. 2003; 361(9368):1519-20. [PubMed: 12737864]

77. Behrman AJ, Shofer FS. Tuberculosis exposure and control in an urban emergency department. Ann Emerg Med. 1998; 31(3):370-5. [PubMed: 9506496] 
78. Fusco FM, Schilling S, De Iaco G, et al. Infection control management of patients with suspected highly infectious diseases in emergency departments: data from a survey in 41 facilities in 14 European countries. BMC Infect Dis. 2012; 12:27. [PubMed: 22284435]

79. Santos CD, Bristow RB, Vorenkamp JV. Which health care workers were most affected during the spring 2009 H1N1 pandemic? Disaster Med Public Health Prep. 2010; 4(1):47-54. [PubMed: 20389195]

80. Centers for Disease Control and Prevention. Occupational transmission of Neisseria meningitidis California, 2009. MMWR Morb Mortal Wkly Rep. 2010; 59(45):1480-3. [PubMed: 21085089]

81. Cruz AT, Patel B, DiStefano MC, et al. Outside the box and into thick air: implementation of an exterior mobile pediatric emergency response team for North American H1N1 (swine) influenza virus in Houston, Texas. Ann Emerg Med. 2010; 55(1):23-31. [PubMed: 19837479]

82. Turnberg W, Daniell W, Seixas N, et al. Appraisal of recommended respiratory infection control practices in primary care and emergency department settings. Am J Infect Control. 2008; 36(4): 268-75. [PubMed: 18455047]

83. May L, Lung D, Harter K. An intervention to improve compliance with transmission precautions for influenza in the emergency department: successes and challenges. J Emerg Med. 2012; 42(1): 79-85. [PubMed: 20452164]

84. Moore D, Gamage B, Bryce E, et al. Protecting health care workers from SARS and other respiratory pathogens: organizational and individual factors that affect adherence to infection control guidelines. Am J Infect Control. 2005; 33(2):88-96. [PubMed: 15761408]

85. Rothman RE, Irvin CB, Moran GJ, et al. Respiratory hygiene in the emergency department. Ann Emerg Med. 2006; 48(5):570-82. [PubMed: 17052558]

86. Longtin Y, Akakpo C, Rutschmann OT, et al. Evaluation of patients' mask use after the implementation of cough etiquette in the emergency department. Infect Control Hosp Epidemiol. 2009; 30(9):904-8. [PubMed: 19622049]

87. Lee DC, Barlas D, Ryan JG, et al. Methicillin-resistant Staphylococcus aureus and vancomycinresistant enterococci: prevalence and predictors of colonization in patients presenting to the emergency department from nursing homes. J Am Geriatr Soc. 2002; 50(8):1463-5. [PubMed: 12165014]

88. Schechter-Perkins EM, Mitchell PM, Murray KA, et al. Prevalence and predictors of nasal and extranasal staphylococcal colonization in patients presenting to the emergency department. Ann Emerg Med. 2011; 57(5):492-9. [PubMed: 21239081]

89. Wakatake H, Fujitani S, Kodama T, et al. Positive clinical risk factors predict a high rate of methicillin-resistant Staphylococcus aureus colonization in emergency department patients. Am J Infect Control. 2012; 40(10):988-91. [PubMed: 22627097]

90. Lu SY, Chang FY, Cheng CC, et al. Methicillin-resistant Staphylococcus aureus nasal colonization among adult patients visiting emergency department in a medical center in Taiwan. PLoS One. 2011; 6(6):e18620. [PubMed: 21695178]

91. Ro YS, Shin SD, Noh H, Cho SI. Prevalence of positive carriage of tuberculosis, methicillinresistant Staphylococcus aureus, and vancomycin-resistant Enterococci in patients transported by ambulance: a single center observational study. J Prev Med Public Health. 2012; 45(3):174-80. [PubMed: 22712044]

92. Dantas SR, Moretti-Branchini ML. Impact of antibiotic-resistant pathogens colonizing the respiratory secretions of patients in an extended-care area of the emergency department. Infect Control Hosp Epidemiol. 2003; 24(5):351-5. [PubMed: 12785409]

93. Martirosian G, Szczesny A, Silva J Jr. Clostridium difficile in emergency room. Anaerobe. 2005; 11(5):258-61. [PubMed: 16701581]

94. Shin BM, Moon SJ, Kim YS, et al. Characterization of cases of Clostridium difficile infection (CDI) presenting at an emergency room: molecular and clinical features differentiate communityonset hospital-associated and community-associated CDI in a tertiary care hospital. J Clin Microbiol. 2011; 49(6):2161-5. [PubMed: 21471341]

95. Vardy J, Love AJ, Dignon N. Outbreak of acute gastroenteritis among emergency department staff. Emerg Med J. 2007; 24(10):699-702. [PubMed: 17901269] 
96. Pallin DJ, Camargo CA Jr. Yokoe DS, et al. Variability of Contact Precaution Policies in US Emergency Departments. Infect Control Hosp Epidemiol. 2014; 35(3):310-2. [PubMed: 24521599]

97. Kac G, Grohs P, Durieux P, et al. Impact of electronic alerts on isolation precautions for patients with multidrug-resistant bacteria. Arch Intern Med. 2007; 167(19):2086-90. [PubMed: 17954803]

98. Kho AN, Dexter PR, Warvel JS, et al. An effective computerized reminder for contact isolation of patients colonized or infected with resistant organisms. Int J Med Inform. 2008; 77(3):194-8. [PubMed: 17398145]

99. Eveillard M, Leroy C, Teissiere F, et al. Impact of selective screening in the emergency department on meticillin-resistant Staphylococcus aureus control programmes. J Hosp Infect. 2006; 63(4): 380-4. [PubMed: 16759741]

100. Centers for Disease Control and Prevention. Immunization of health-care personnel: recommendations of the Advisory Committee on Immunization Practices (ACIP). MMWR Recomm Rep. 2011; 60(RR-7):1-45.

101. Saluja I, Theakston KD, Kaczorowski J. Influenza vaccination rate among emergency department personnel: a survey of four teaching hospitals. CJEM. 2005; 7(1):17-21. [PubMed: 17355649]

102. Piccirillo B, Gaeta T. Survey on use of and attitudes toward influenza vaccination among emergency department staff in a New York metropolitan hospital. Infect Control Hosp Epidemiol. 2006; 27(6):618-22. [PubMed: 16755483]

103. Rueckmann E, Shah MN, Humiston SG. Influenza vaccination among emergency medical services and emergency department personnel. Prehosp Emerg Care. 2009; 13(1):1-5. [PubMed: 19145517]

104. Centers for Disease Control and Prevention. Prevention and control of influenza with vaccines: recommendations of the Advisory Committee on Immunization Practices (ACIP), 2011. MMWR Morb Mortal Wkly Rep. 2011; 60(33):1128-32. [PubMed: 21866086]

105. Boyce JM, Potter-Bynoe G, Chenevert C, King T. Environmental contamination due to methicillin-resistant Staphylococcus aureus: possible infection control implications. Infect Control Hosp Epidemiol. 1997; 18(9):622-7. [PubMed: 9309433]

106. Boyce JM, Havill NL, Otter JA, Adams NM. Widespread environmental contamination associated with patients with diarrhea and methicillin-resistant Staphylococcus aureus colonization of the gastrointestinal tract. Infect Control Hosp Epidemiol. 2007; 28(10):1142-7. [PubMed: 17828690]

107. Morgan DJ, Rogawski E, Thom KA, et al. Transfer of multidrug-resistant bacteria to healthcare workers' gloves and gowns after patient contact increases with environmental contamination. Crit Care Med. 2012; 40(4):1045-51. [PubMed: 22202707]

108. Huang SS, Datta R, Platt R. Risk of acquiring antibiotic-resistant bacteria from prior room occupants. Arch Intern Med. 2006; 166(18):1945-51. [PubMed: 17030826]

109. Drees M, Snydman DR, Schmid CH, et al. Prior environmental contamination increases the risk of acquisition of vancomycin-resistant enterococci. Clin Infect Dis. 2008; 46(5):678-85. [PubMed: 18230044]

110. Rutala, WA.; Weber, DJ. Guideline for disinfection and sterilization in healthcare facilities. 2008. [2/15/2014]; Available from: http://www.cdc.gov/hicpac/pdf/guidelines/ disinfection_nov_2008.pdf

111. Otter JA, Passaretti CL, French GL, et al. Low frequency of environmental contamination with methicillin-resistant Staphylococcus aureus in an inner city emergency department and a human immunodeficiency virus outpatient clinic. Am J Infect Control. 2011; 39(2):151-3. [PubMed: 20888076]

112. Kei J, Richards JR. The prevalence of methicillin-resistant Staphylococcus aureus on inanimate objects in an urban emergency department. J Emerg Med. 2011; 41(2):124-7. [PubMed: 19111424]

113. Pugliese A, Garcia AJ, Dobson W, et al. The prevalence of bacterial contamination of standard keyboards in an urban ED. Am J Emerg Med. 2011; 29(8):954-5. [PubMed: 21820257]

114. Jones JS, Hoerle D, Riekse R. Stethoscopes: a potential vector of infection? Ann Emerg Med. 1995; 26(3):296-9. [PubMed: 7661417] 
115. Nunez S, Moreno A, Green K, Villar J. The stethoscope in the emergency department: a vector of infection? Epidemiol Infect. 2000; 124(2):233-7. [PubMed: 10813148]

116. Tang PH, Worster A, Srigley JA, Main CL. Examination of staphylococcal stethoscope contamination in the emergency department (pilot) study (EXSSCITED pilot study). CJEM. 2011; 13(4):239-44. [PubMed: 21722552]

117. Klevens RM, Edwards JR, Richards CL Jr. et al. Estimating health care-associated infections and deaths in U.S. hospitals, 2002. Public Health Rep. 2007; 122(2):160-6. [PubMed: 17357358]

118. Mermel LA. Prevention of intravascular catheter-related infections. Ann Intern Med. 2000; 132(5):391-402. [PubMed: 10691590]

119. Warren DK, Quadir WW, Hollenbeak CS, et al. Attributable cost of catheter-associated bloodstream infections among intensive care patients in a nonteaching hospital. Crit Care Med. 2006; 34(8):2084-9. [PubMed: 16763511]

120. Pittet D, Tarara D, Wenzel RP. Nosocomial bloodstream infection in critically ill patients: excess length of stay, extra costs, and attributable mortality. JAMA. 1994; 271(20):1598-601. [PubMed: 8182812]

121. Digiovine B, Chenoweth C, Watts C, Higgins M. The attributable mortality and costs of primary nosocomial bloodstream infections in the intensive care unit. Am J Respir Crit Care Med. 1999; 160(3):976-81. [PubMed: 10471627]

122. Blot SI, Depuydt P, Annemans L, et al. Clinical and economic outcomes in critically ill patients with nosocomial catheter-related bloodstream infections. Clin Infect Dis. 2005; 41(11):1591-8. [PubMed: 16267731]

123. Garrouste-Orgeas M, Timsit JF, et al. Excess risk of death from intensive care unit-acquired nosocomial bloodstream infections: a reappraisal. Clin Infect Dis. 2006; 42(8):1118-26. [PubMed: 16575729]

124. Steele R, Irvin CB. Central line mechanical complication rate in emergency medicine patients. Acad Emerg Med. 2001; 8(2):204-7. [PubMed: 11157303]

125. Theodoro D, Bausano B, Lewis L, et al. A descriptive comparison of ultrasound-guided central venous cannulation of the internal jugular vein to landmark-based subclavian vein cannulation. Acad Emerg Med. 2010; 17(4):416-22. [PubMed: 20370781]

126. LeMaster C, Agrawal A, Hou P, Schuur J. Systematic review of emergency department central venous and arterial catheter infection. Int J Emerg Med. 2010; 3(4):409-23. [PubMed: 21373313]

127. Nagashima G, Kikuchi T, Tsuyuzaki H, et al. To reduce catheter-related bloodstream infections: is the subclavian route better than the jugular route for central venous catheterization? J Infect Chemother. 2006; 12(6):363-5. [PubMed: 17235641]

128. Trick WE, Miranda J, Evans AT, et al. Prospective cohort study of central venous catheters among internal medicine ward patients. Am J Infect Control. 2006; 34(10):636-41. [PubMed: 17161738]

129. Chiang VW, Baskin MN. Uses and complications of central venous catheters inserted in a pediatric emergency department. Pediatr Emerg Care. 2000; 16(4):230-2. [PubMed: 10966338]

130. Ferguson M, Max MH, Marshall W. Emergency department infraclavicular subclavian vein catheterization in patients with multiple injuries and burns. South Med J. 1988; 81(4):433-5. [PubMed: 3358164]

131. LeMaster CH, Schuur JD, Pandya D, et al. Infection and natural history of emergency department-placed central venous catheters. Ann Emerg Med. 2010; 56(5):492-7. [PubMed: 20869789]

132. Guzzo JL, Seagull FJ, Bochicchio GV, et al. Mentors decrease compliance with best sterile practices during central venous catheter placement in the trauma resuscitation unit. Surg Infect (Larchmt). 2006; 7(1):15-20. [PubMed: 16509781]

133. Xiao Y, Seagull FJ, Bochicchio GV, et al. Video-based training increases sterile-technique compliance during central venous catheter insertion. Crit Care Med. 2007; 35(5):1302-6. [PubMed: 17414726]

134. Barsuk JH, Cohen ER, Feinglass J, et al. Use of simulation-based education to reduce catheterrelated bloodstream infections. Arch Intern Med. 2009; 169(15):1420-3. [PubMed: 19667306]

Ann Emerg Med. Author manuscript; available in PMC 2015 September 01. 
135. Marschall J, Mermel LA, Classen D, et al. Strategies to prevent central line-associated bloodstream infections in acute care hospitals. Infect Control Hosp Epidemiol. 2008; 29(Suppl 1):S22-30. [PubMed: 18840085]

136. O'Grady NP, Alexander M, Burns LA, et al. Guidelines for the prevention of intravascular catheter-related infections. Clin Infect Dis. 2011; 52(9):e162-93. [PubMed: 21460264]

137. Centers for Disease Control and Prevention. Reduction in central line-associated bloodstream infections among patients in intensive care units: Pennsylvania, April 2001-March 2005. MMWR Morb Mortal Wkly Rep. 2005; 54(40):1013-6. [PubMed: 16224448]

138. Pronovost $\mathrm{P}$, Needham D, Berenholtz $\mathrm{S}$, et al. An intervention to decrease catheter-related bloodstream infections in the ICU. N Engl J Med. 2006; 355(26):2725-32. [PubMed: 17192537]

139. Lemaster $\mathrm{CH}$, Hoffart $\mathrm{N}$, Chafe $\mathrm{T}$, et al. Implementing the central venous catheter infection prevention bundle in the emergency department: experiences among early adopters. Ann Emerg Med. Oct 10.2013 Epub ahead of print.

140. Pujol M, Hornero A, Saballs M, et al. Clinical epidemiology and outcomes of peripheral venous catheter-related bloodstream infections at a university-affiliated hospital. J Hosp Infect. 2007; 67(1):22-9. [PubMed: 17719678]

141. Trinh TT, Chan PA, Edwards O, et al. Peripheral venous catheter-related Staphylococcus aureus bacteremia. Infect Control Hosp Epidemiol. 2011; 32(6):579-83. [PubMed: 21558770]

142. Fakih MG, Jones K, Rey JE, et al. Peripheral venous catheter care in the emergency department: education and feedback lead to marked improvements. Am J Infect Control. 2012

143. Shokoohi H, Boniface K, McCarthy M, et al. Ultrasound-guided peripheral intravenous access program is associated with a marked reduction in central venous catheter use in noncritically ill emergency department patients. Ann Emerg Med. 2013; 61(2):198-203. [PubMed: 23141920]

144. Adhikari S, Blaivas M, Morrison D, Lander L. Comparison of infection rates among ultrasoundguided versus traditionally placed peripheral intravenous lines. J Ultrasound Med. 2010; 29(5): 741-7. [PubMed: 20427786]

145. Umscheid CA, Mitchell MD, Doshi JA, et al. Estimating the proportion of healthcare-associated infections that are reasonably preventable and the related mortality and costs. Infect Control Hosp Epidemiol. 2011; 32(2):101-14. [PubMed: 21460463]

146. Lo E, Nicolle L, Classen D, et al. Strategies to prevent catheter-associated urinary tract infections in acute care hospitals. Infect Control Hosp Epidemiol. 2008; 29(Suppl 1):S41-50. [PubMed: 18840088]

147. Gould CV, Umscheid CA, Agarwal RK, et al. Guideline for prevention of catheter-associated urinary tract infections 2009. Infect Control Hosp Epidemiol. 2010; 31(4):319-26. [PubMed: 20156062]

148. Gardam MA, Amihod B, Orenstein P, et al. Overutilization of indwelling urinary catheters and the development of nosocomial urinary tract infections. Clin Perform Qual Health Care. 1998; 6(3):99-102. [PubMed: 10182561]

149. Bhatia N, Daga MK, Garg S, Prakash SK. Urinary catheterization in medical wards. J Glob Infect Dis. 2010; 2(2):83-90. [PubMed: 20606958]

150. Gokula RR, Hickner JA, Smith MA. Inappropriate use of urinary catheters in elderly patients at a midwestern community teaching hospital. Am J Infect Control. 2004; 32(4):196-9. [PubMed: 15175612]

151. Fakih MG, Shemes SP, Pena ME, et al. Urinary catheters in the emergency department: very elderly women are at high risk for unnecessary utilization. Am J Infect Control. 2010; 38(9):6838. [PubMed: 21034978]

152. Hazelett SE, Tsai M, Gareri M, Allen K. The association between indwelling urinary catheter use in the elderly and urinary tract infection in acute care. BMC Geriatr. 2006; 6:15. [PubMed: 17038177]

153. Gokula RM, Smith MA, Hickner J. Emergency room staff education and use of a urinary catheter indication sheet improves appropriate use of foley catheters. Am J Infect Control. 2007; 35(9): 589-93. [PubMed: 17980237]

154. Fakih MG, Pena ME, Shemes S, et al. Effect of establishing guidelines on appropriate urinary catheter placement. Acad Emerg Med. 2010; 17(3):337-40. [PubMed: 20370769] 
155. Dyc NG, Pena ME, Shemes SP, et al. The effect of resident peer-to-peer education on compliance with urinary catheter placement indications in the emergency department. Postgrad Med J. 2011; 87(1034):814-8. [PubMed: 22039221]

156. Burnett KP, Erickson D, Hunt A, et al. Strategies to prevent urinary tract infection from urinary catheter insertion in the emergency department. J Emerg Nurs. 2010; 36(6):546-50. [PubMed: 21078466]

157. Fakih MG, Rey JE, Pena ME, et al. Sustained reductions in urinary catheter use over 5 years: bedside nurses view themselves responsible for evaluation of catheter necessity. Am J Infect Control. 2013; 41(3):236-9. [PubMed: 22980514]

158. Fakih MG, Watson SR, Greene MT, et al. Reducing inappropriate urinary catheter use: a statewide effort. Arch Intern Med. 2012; 172(3):255-60. [PubMed: 22231611]

159. Rello J, Ollendorf DA, Oster G, et al. Epidemiology and outcomes of ventilator-associated pneumonia in a large US database. Chest. 2002; 122(6):2115-21. [PubMed: 12475855]

160. Muscedere JG, Day A, Heyland DK. Mortality, attributable mortality, and clinical events as end points for clinical trials of ventilator-associated pneumonia and hospital-acquired pneumonia. Clin Infect Dis. 2010; 51(Suppl 1):S120-5. [PubMed: 20597661]

161. Eckert MJ, Davis KA, Reed RL, et al. Urgent airways after trauma: who gets pneumonia? J Trauma. 2004; 57(4):750-5. [PubMed: 15514528]

162. Eckert MJ, Wade TE, Davis KA, et al. Ventilator-associated pneumonia after combined burn and trauma is caused by associated injuries and not the burn wound. J Burn Care Res. 2006; 27(4): 457-62. [PubMed: 16819348]

163. Eckert MJ, Davis KA, Reed RL, et al. Ventilator-associated pneumonia, like real estate: location really matters. J Trauma. 2006; 60(1):104-10. [PubMed: 16456443]

164. Evans HL, Zonies DH, Warner KJ, et al. Timing of intubation and ventilator-associated pneumonia following injury. Arch Surg. 2010; 145(11):1041-6. [PubMed: 21079091]

165. Evans HL, Warner K, Bulger EM, et al. Pre-hospital intubation factors and pneumonia in trauma patients. Surg Infect (Larchmt). 2011; 12(5):339-44. [PubMed: 21933010]

166. Carr BG, Kaye AJ, Wiebe DJ, et al. Emergency department length of stay: a major risk factor for pneumonia in intubated blunt trauma patients. J Trauma. 2007; 63(1):9-12. [PubMed: 17622862]

167. Coffin SE, Klompas M, Classen D, et al. Strategies to prevent ventilator-associated pneumonia in acute care hospitals. Infect Control Hosp Epidemiol. 2008; 29(Suppl 1):S31-40. [PubMed: 18840087]

168. Muscedere J, Dodek P, Keenan S, et al. Comprehensive evidence-based clinical practice guidelines for ventilator-associated pneumonia: prevention. J Crit Care. 2008; 23(1):126-37. [PubMed: 18359430]

169. Berenholtz SM, Pham JC, Thompson DA, et al. Collaborative cohort study of an intervention to reduce ventilator-associated pneumonia in the intensive care unit. Infect Control Hosp Epidemiol. 2011; 32(4):305-14. [PubMed: 21460481]

170. Sinuff T, Muscedere J, Cook DJ, et al. Implementation of clinical practice guidelines for ventilator-associated pneumonia: a multicenter prospective study. Crit Care Med. 2013; 41(1): 15-23. [PubMed: 23222254]

171. McCoy T, Fields W, Kent N. Evaluation of emergency department evidence-based practices to prevent the incidence of ventilator-acquired pneumonia. J Nurs Care Qual. 2012; 27(1):83-8. [PubMed: 21623233]

172. Weingart SD, Menaker J, Truong H, et al. Trauma patients can be safely extubated in the emergency department. J Emerg Med. 2011; 40(2):235-9. [PubMed: 19703744]

173. Frazee BW, Fahimi J, Lambert L, Nagdev A. Emergency department ultrasonographic probe contamination and experimental model of probe disinfection. Ann Emerg Med. 2011; 58(1):5663. [PubMed: 21256624]

174. Sanz GE, Theoret J, Liao MM, et al. Bacterial contamination and cleanliness of emergency department ultrasound probes. CJEM. 2011; 13(6):384-9. [PubMed: 22436476]

175. Rodriguez G, Quan D. Bacterial growth on ED ultrasound machines. Am J Emerg Med. 2011; 29(7):816-7. [PubMed: 21676573] 
176. Ma ST, Yeung AC, Chan PK, Graham CA. Transvaginal ultrasound probe contamination by the human papillomavirus in the emergency department. Emerg Med J. 2012

177. Stone PW, Pogorzelska-Maziarz M, Herzig CT, et al. State of infection prevention in US hospitals enrolled in the National Health and Safety Network. Am J Infect Control. 2014; 42(2): 94-9. [PubMed: 24485365]

178. Birnbach DJ, Nevo I, Scheinman SR, et al. Patient safety begins with proper planning: a quantitative method to improve hospital design. Qual Saf Health Care. 2010; 19(5):462-5. [PubMed: 20584700]

179. Terp S, Krishnadasan A, Bowen W, et al. Introduction of rapid MRSA PCR testing and antibiotic selection among hospitalized patients with purulent skin infections. Clin Infect Dis. Jan 22.2014 Epub ahead of print.

180. Gilligan P, Quirke M, Winder S, Humphreys H. Impact of admission screening for methicillinresistant Staphylococcus aureus on the length of stay in an emergency department. J Hosp Infect. 2010; 75(2):99-102. [PubMed: 20381911]

181. Huang SS, Septimus E, Kleinman K, et al. Targeted versus universal decolonization to prevent ICU infection. N Engl J Med. 2013; 368(24):2255-65. [PubMed: 23718152]

182. May L, Cosgrove S, L'Archeveque M, et al. A call to action for antimicrobial stewardship in the emergency department: approaches and strategies. Ann Emerg Med. 2013; 62(1):69-77. [PubMed: 23122955] 


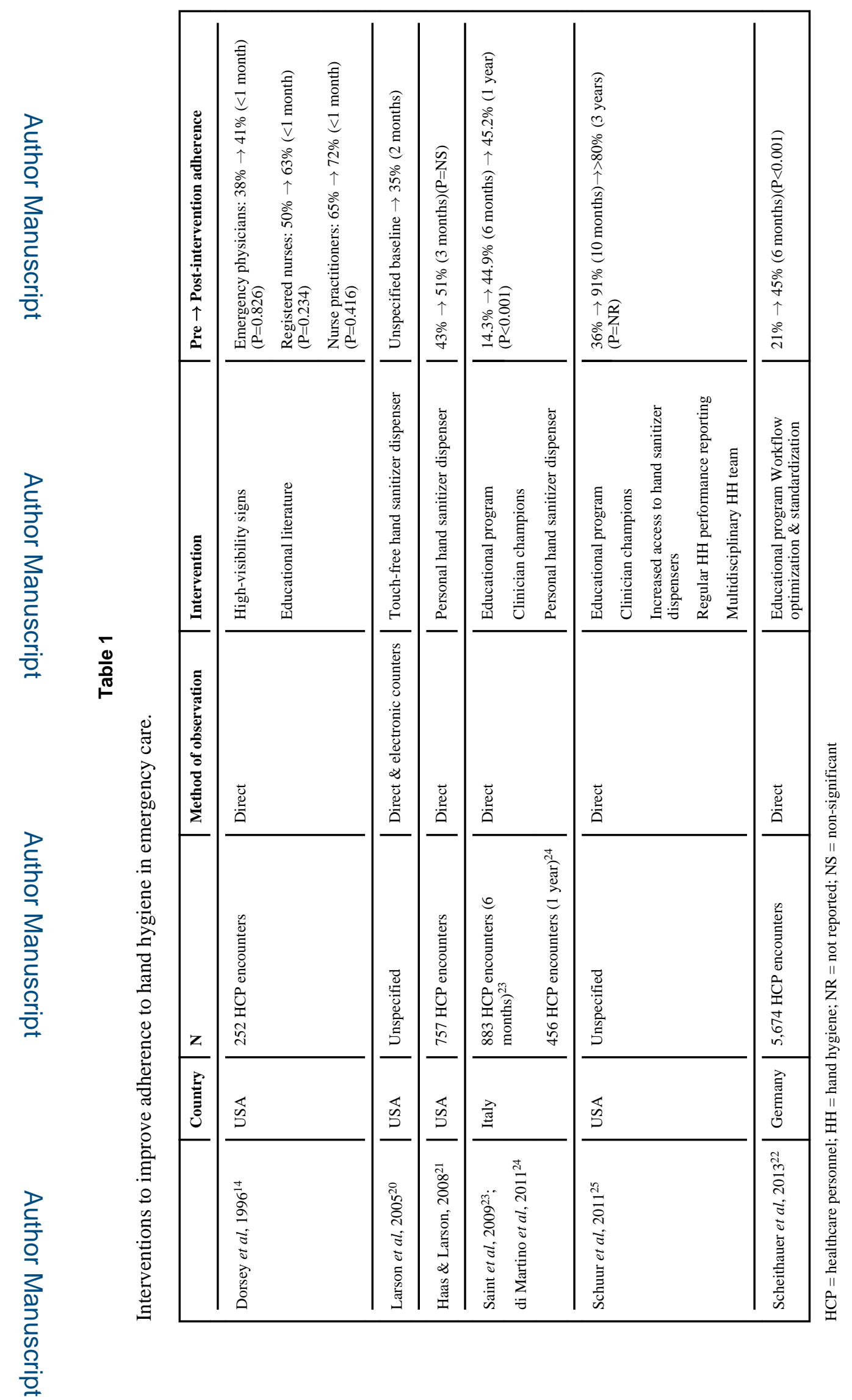

Ann Emerg Med. Author manuscript; available in PMC 2015 September 01. 


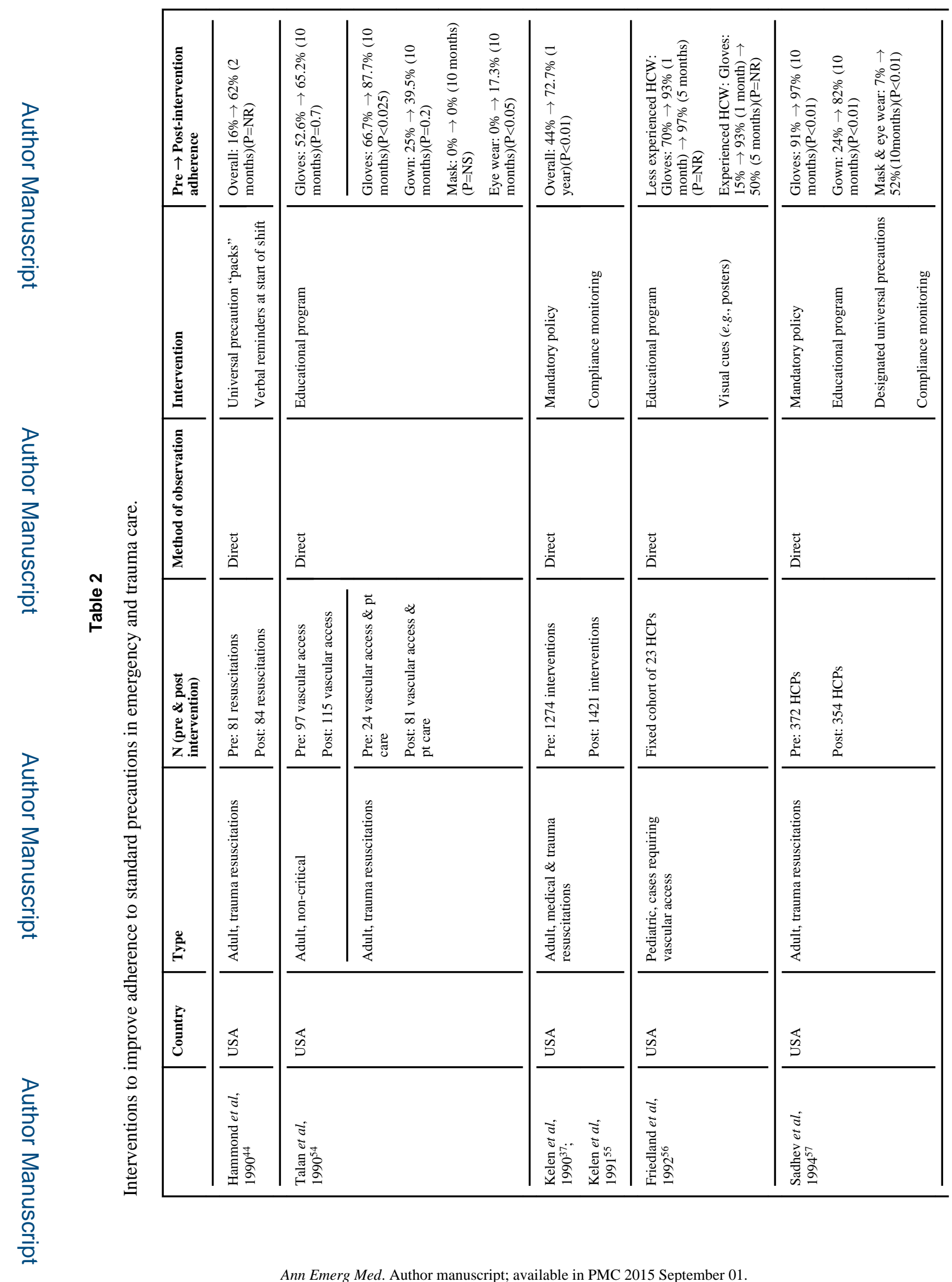




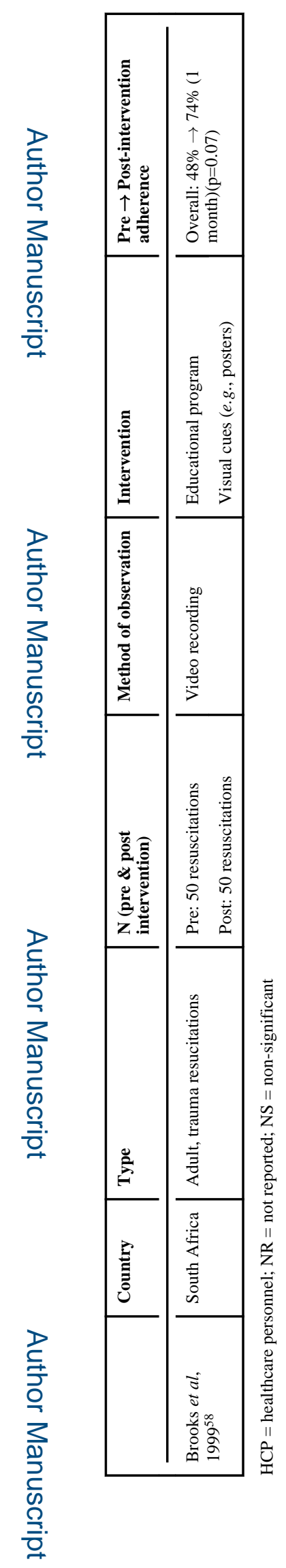




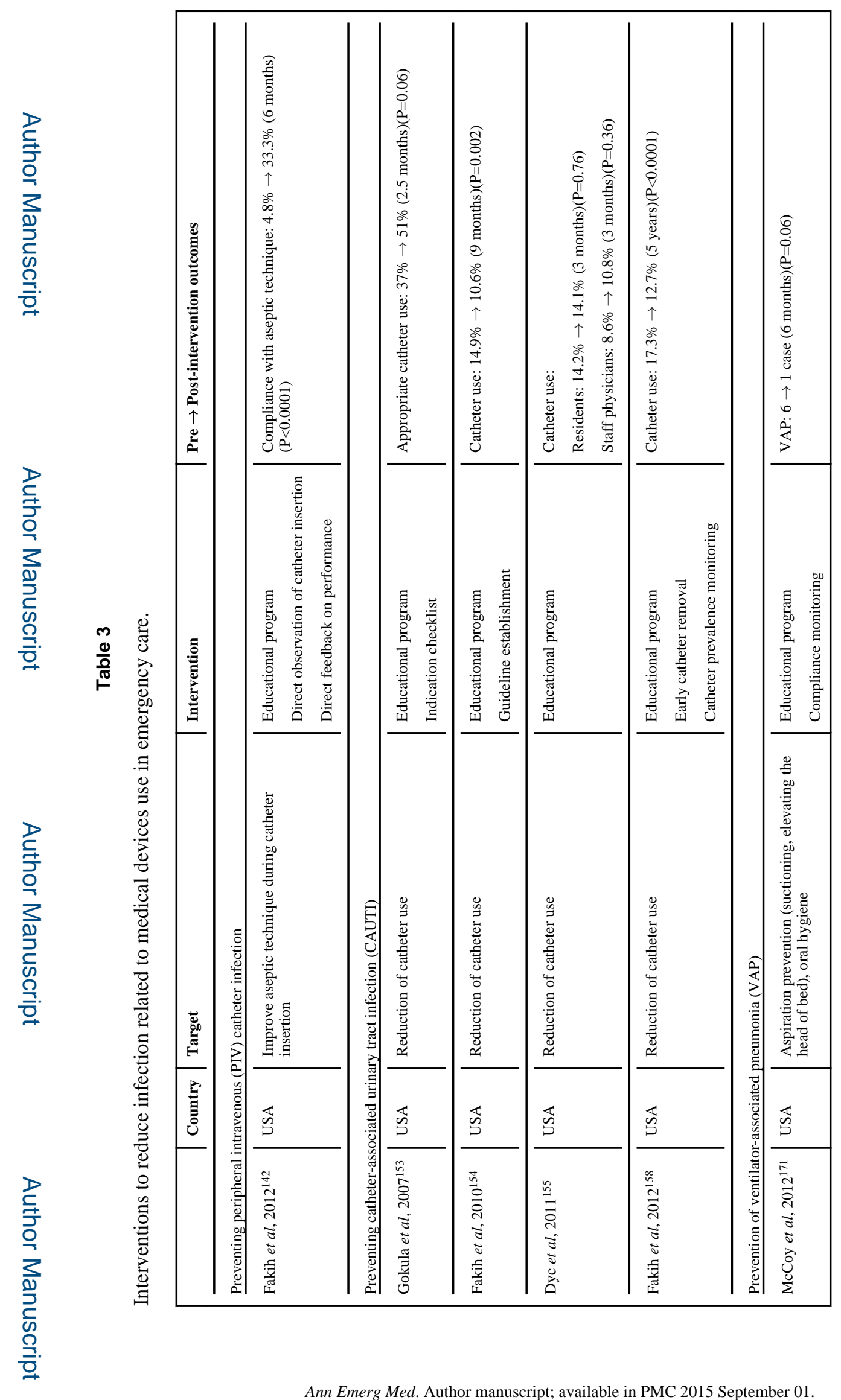




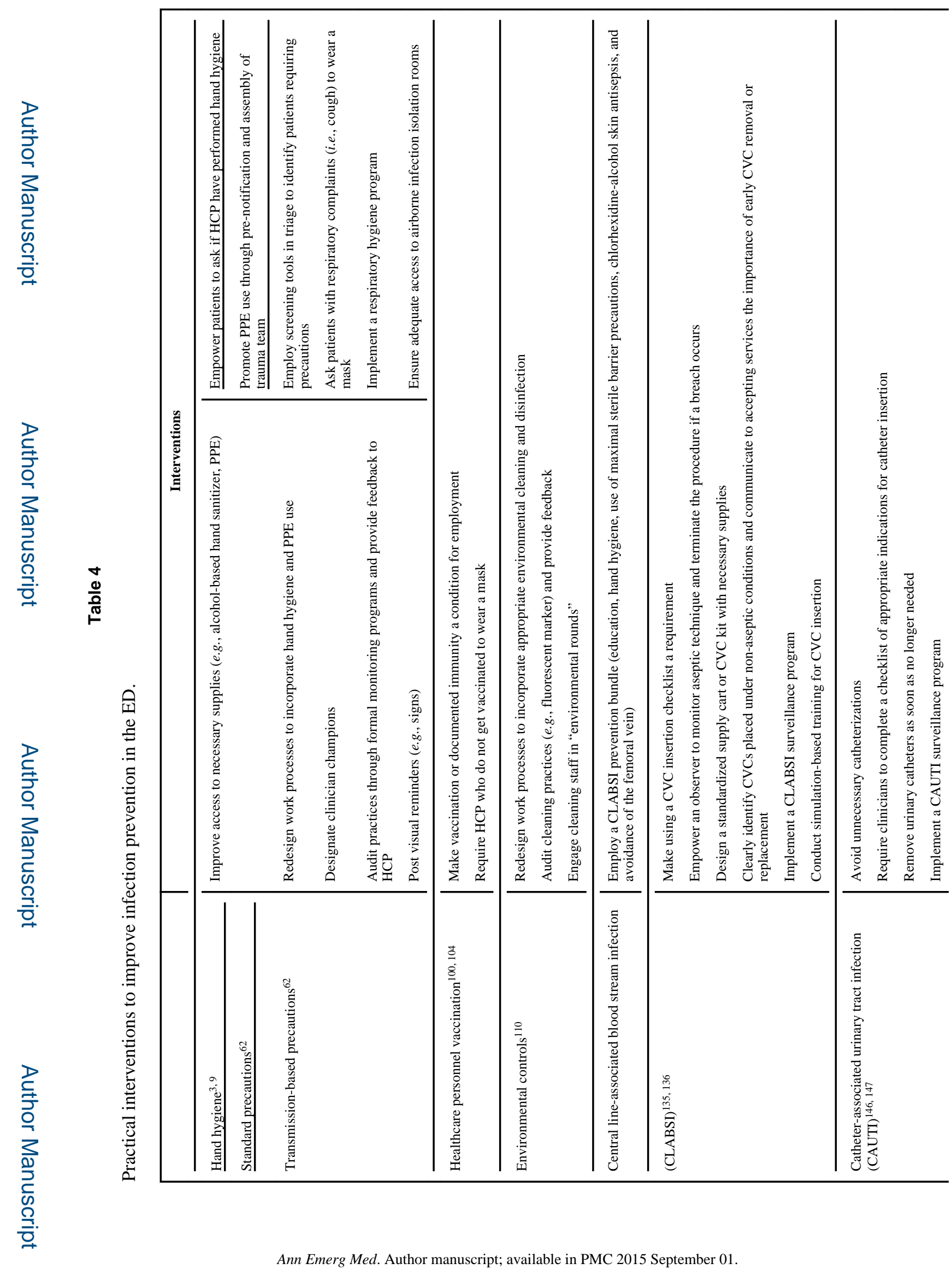




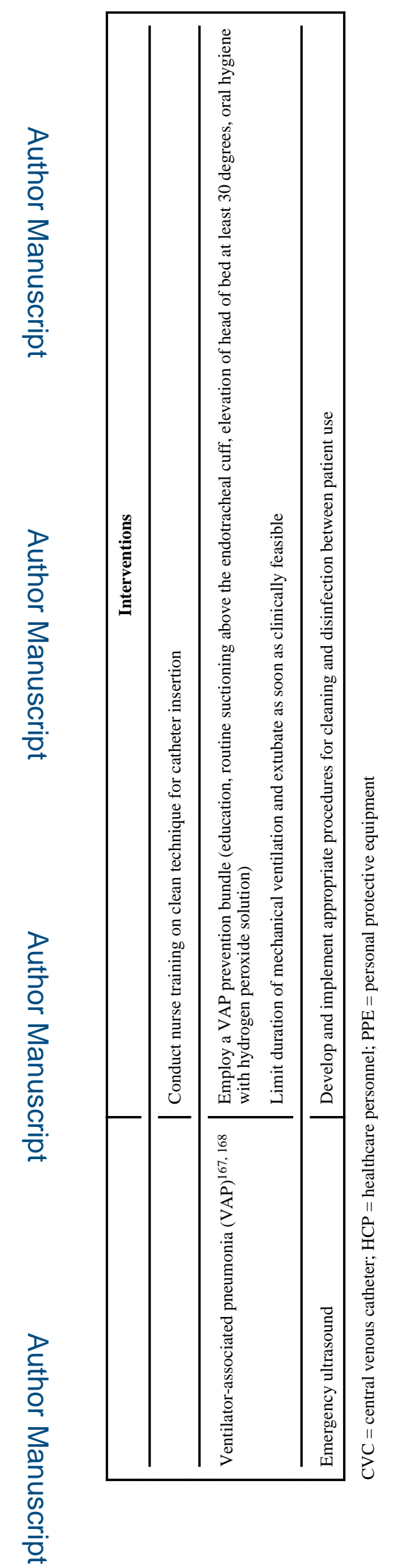

Ann Emerg Med. Author manuscript; available in PMC 2015 September 01. 